\title{
BIOMEDICAL NEUTRON RESEARCH AT THE \\ CALIFORNIUM USER FACILITY FOR NEUTRON SCIENCE
}

R. C. Martin, T. E. Byrne, ${ }^{*}$ and L. F. Miller ${ }^{\dagger}$

Chemical Technology Division

Oak Ridge National Laboratory ${ }^{\ddagger}$

P.O. Box 2008

Oak Ridge, TN 37831-6385
RECEVER

APR 221397

OSTI

* Roane State Community College, Harriman, TN 37748

${ }^{\dagger}$ The University of Tennessee, Knoxville, TN 37996

To be presented at the

4th International Conference on Methods

and Applications of Radioanalytical Chemistry

Kona, Hawaii

April 6-11, 1997

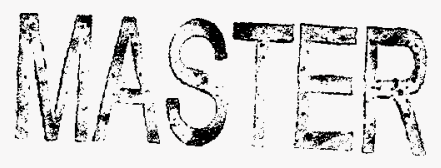

"The submitted manuscript has been authored by a contractor of the U.S.

Government under contract No. DEAC05-96OR22464. Accordingly, the U.S. Government retains a

nonexciusive. royalty-free license to publish or reproduce the published form of this contribution. or allow others to

do so, for U.S. government purposes."

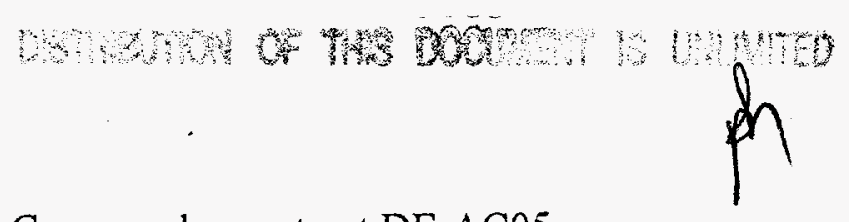

†Managed by Lockheed Martin Energy Research Corp., under contract DE-AC0596OR22464 with the U.S. Department of Energy. 


\section{DISCLAIMER}

This report was prepared as an account of work sponsored by an agency of the United States Government. Neither the United States Government nor any agency thereof, nor any of their employees, make any warranty, express or implied, or assumes any legal liability or responsibility for the accuracy, completeness, or usefulness of any information, apparatus, product, or process disclosed, or represents that its use would not infringe privately owned rights. Reference herein to any specific commercial product, process, or service by trade name, trademark, manufacturer, or otherwise does not necessarily constitute or imply its endorsement, recommendation, or favoring by the United States Government or any agency thereof. The views and opinions of authors expressed herein do not necessarily state or reflect those of the United States Government or any agency thereof. 


\section{DISCLAIMER}

Portions of this document may be illegible in electronic image products. Images are produced from the best available original document. 
The Californium User Facility for Neutron Science has been established at Oak Ridge National Laboratory (ORNL). The Californium User Facility (CUF) is a part of the larger Californium Facility, which fabricates and stores compact ${ }^{252} \mathrm{Cf}$ neutron sources for worldwide distribution. The CUF can provide a cost-effective option for research with ${ }^{252} \mathrm{Cf}$ sources. Three projects at the CUF that demonstrate the versatility of ${ }^{252} \mathrm{Cf}$ for biological and biomedical neutron-based research are described: future establishment of a ${ }^{252} \mathrm{Cf}$-based neutron activation analysis system, ongoing work to produce miniature high-intensity, remotely afterloaded ${ }^{252} \mathrm{Cf}$ sources for tumor therapy, and a recent experiment that irradiated living human lung cancer cells impregnated with experimental boron compounds to test their effectiveness for boron neutron capture therapy.

\section{Introduction}

The heavy isotope ${ }^{252} \mathrm{Cf}$ is an intense neutron emitter that can be conveniently encapsulated in compact, portable neutron sources. ${ }^{1}$ Californium- 252 is used in a variety of industrial and research applications such as elemental neutron activation analysis, neutron radiography, reactor startup sources, nuclear material and waste assays, and tumor therapy. ${ }^{2}$ Californium-252 has a half-life of 2.645 years and decays by alpha emission (96.9\%) and spontaneous fission (3.1\%), with $1 \mathrm{mg}$ of ${ }^{252} \mathrm{Cf}$ generating $2.3 \times 10^{9}$ neutrons/s ( $2.1 \mathrm{MeV}$ average energy). Nearly the entire world's supply of ${ }^{252} \mathrm{Cf}$ is produced at the High Flux Isotope Reactor (HFIR) at ORNL and

processed, purified, and encapsulated for shipment at the neighboring Radiochemical Engineering Development Center (REDC). The REDC Californium Facility also stores the national inventory of sealed ${ }^{252} \mathrm{Cf}$ neutron sources for university, research, and government loans. 
The REDC has recently established the Californium User Facility for Neutron Science for use by academic, industrial, and governmental researchers. This Californium User Facility is located within the Californium Facility and encompasses two uncontaminated walk-in hot cells designated as Cell $\mathrm{B}$ and $\mathrm{Cell} \mathrm{C}$, the water-filled ${ }^{252} \mathrm{Cf}$ storage pool, available neutron sources, pneumatic transfer capabilities, and associated infrastructural and technical support. Figure 1 is a floor plan showing the location of Cells B and C and the storage pool (location 8). The REDC also has in-house analytical chemistry support for alpha, beta, and gamma spectroscopy.

The CUF is a unique national resource that can provide a cost-effective option for exploratory studies with ${ }^{252} \mathrm{Cf}$ sources without the capital outlay or regulatory issues involved in source fabrication, purchase, or loan. Previous and potential applications of the CUF include thermal, fast, and prompt gamma neutron activation analysis, dosimetry for neutron tumor therapy, and hardness testing of radiation detectors and electronics. This paper focuses on three projects (past, present, and future) at the CUF that demonstrate the versatility of ${ }^{252} \mathrm{Cf}$ for biological and biomedical applications. Information on using the CUF is also provided.

\section{Neutron activation analysis facility}

The Food and Drug Administration (FDA) would like to establish a permanent neutron activation analysis (NAA) facility for analyzing food samples using four $50-\mathrm{mg}{ }^{252} \mathrm{Cf}$ sources. This facility would contain more ${ }^{252} \mathrm{Cf}$ for a single application than any other in the world. Planning is under way to house this system within the CUF with operational assistance provided by collaboration with The University of Tennessee, Knoxville. Although ${ }^{252} \mathrm{Cf}$ cannot match the high neutron fluxes found in a reactor core, the ${ }^{252} \mathrm{Cf}$ sources are never subject to reactor 
downtime and samples larger than those in most reactor pneumatic rabbit systems can be accommodated (40-mL rabbit design from the National Institute of Standards and Technology).

$\mathrm{A}^{252} \mathrm{Cf}$-based NAA system can be very versatile compared with reactor-based systems. The unlimited irradiation times and the use of larger sample rabbits partially offset the lower neutron flux. Gamma heating from ${ }^{252} \mathrm{Cf}$-based activation is insignificant compared with inreactor activation, which is advantageous when irradiating volatile or delicate samples. Repositioning of ${ }^{252} \mathrm{Cf}$ sources around the sample can tailor the ratio of thermal-to-fast neutron flux (and flux magnitude) for either thermal or fast NAA. The large rabbit volumes will permit the use of neutron-absorbing sleeves for spectral tailoring (epithermal and fast NAA) to mitigate specific elemental interferences. The unique flexibility of the CUF also allows nonpneumatic activation of large or odd-shaped samples by arranging ${ }^{252} \mathrm{Cf}$ sources around the sample in-cell for either delayed or prompt gamma spectroscopy.

\section{Californium-252 medical sources for tumor therapy}

The Gershenson Radiation Oncology Center at Wayne State University (WSU), Detroit, Michigan, is the only medical institute in the United States currently using ${ }^{252} \mathrm{Cf}$ sources for tumor therapy. Neutron brachytherapy (i.e., inserting the neutron source directly into or around the tumor) is more effective than conventional photon radiotherapy in treating bulky (late-stage) and hypoxic (oxygen-deficient) tumors. ${ }^{3} \mathrm{~A}^{252} \mathrm{Cf}$ brachytherapy source design called the Applicator Tube (AT) with a maximum of $30 \mu \mathrm{g}$ of ${ }^{252} \mathrm{Cf}$ is currently in use at WSU. Clinicians manually load the sources into the patient followed by treatment times of several hours. The clinicians would like full-strength replacement AT sources, but would prefer stronger sources to reduce treatment times, remotely afterloaded sources to reduce personnel dose, and smaller sources for 
restricted treatment geometries such as brain tumors. Current work at the CUF is geared toward relicensing the AT source for future manufacture at ORNL and developing new high-activity ${ }^{252} \mathrm{Cf}$ brachytherapy sources tailored to an existing gamma-source remote afterloader design.

\section{Cell-killing studies for boron neutron capture therapy (BNCT)}

BNCT is a form of cancer treatment in which a ${ }^{10} \mathrm{~B}$-containing compound is preferentially taken up by tumor cells, followed by thermal neutron irradiation to induce the ${ }^{10} \mathrm{~B}(\mathrm{n}, \alpha)^{7} \mathrm{Li}$ reaction. The resulting $\alpha-{ }^{7} \mathrm{Li}$ pair deposits an average of $2.3 \mathrm{MeV}$ per reaction within a range of $\sim 10 \mu \mathrm{m}$ (comparable to cellular dimensions). A fraction of this energy can kill a cell. Successful BNCT treatments must meet four criteria: (1) ${ }^{10} \mathrm{~B}$ uptake by the tumor mass must be significant, (2) tumor cells must preferentially uptake the boronated compound compared with healthy cells, (3) the incidental radiation damage to healthy tissue must be tolerable, and (4) thermal neutron flux at the tumor must provide acceptable neutron capture rates by ${ }^{10} \mathrm{~B}$ (as a rule of thumb, $\sim 10^{9}$ neutrons $\cdot \mathrm{cm}^{-2} \cdot \mathrm{s}^{-1}$ ). In addition, the boronated compound must not be unacceptably toxic to the healthy cells for the given uptake. A University of Tennessee, Knoxville, project addressed the first two questions for four experimental boron compounds and demonstrated their efficacy in killing living human lung tumor cells in a partially thermalized ${ }^{252} \mathrm{Cf}$ neutron spectrum. These tumor cells were grown in a medium containing the boronated compounds, the cellular uptake and toxicity of each compound were quantified, and the irradiations quantified each compound's enhanced cell killing relative to nonboronated cell standards. 


\section{Experimental Methods}

\section{General irradiation experiments}

A major advantage of the CUF is its accessibility and controlled experimental conditions compared with those of a reactor environment. For example, with an approximately 10:1 neutron:gamma ratio for dose equivalent rate from ${ }^{252} \mathrm{Cf}$, the neutron damage effects are predominant. After hands-on experimental setup inside Cell B or C, personnel are evacuated, the cell is closed, and sealed ${ }^{252} \mathrm{Cf}$ sources are pneumatically transferred into the cell and positioned remotely using manipulators. Individual source strengths from $<1 \mu \mathrm{g}$ to tens of milligrams of ${ }^{252} \mathrm{Cf}$ are available, with total strengths up to $50 \mathrm{mg}\left(\sim 10^{11}\right.$ neutrons/s) permitted in Cell $\mathrm{C}$ and $3.7 \mathrm{mg}$ in Cell B. The storage pool is a large water tank containing the CUF inventory of sealed ${ }^{252} \mathrm{Cf}$ sources (typically up to several hundred milligrams of ${ }^{252} \mathrm{Cf}$ ). For pool irradiation, a sample can either be pneumatically transferred into the storage lattice and the neutron field tailored by rearranging the neighboring sources, or larger samples and watertight experiments can be physically lowered into the underwater neutron field.

An ongoing project typifies an in-cell experimental configuration. To test the radiation hardness of an avalanche photodiode (APD) detector to be used for high-energy physics experiments at the CERN accelerator, a team from Northeastern University and the University of Minnesota assembled an experiment in Cell C in which 28 to $48 \mathrm{mg}$ of ${ }^{252} \mathrm{Cf}$ was used to approximate the expected in-service neutron fluence. ${ }^{4}$ Real-time data acquisition and computer control of the experiment were provided by cables between the out-of-cell computer hardware and the in-cell experiment. 


\section{Neutron activation analysis facility}

The source-sample irradiation module will be located within the ${ }^{252} \mathrm{Cf}$ storage pool. An existing pneumatic sample transfer and control system, which was fabricated elsewhere for FDA use, can be installed in Cell B and coupled to the irradiation module after modification and testing. The transfer system will parallel existing transfer lines into the pool (Figure 1). The assay station and gamma detector will be located in Cell B near a shielded window for viewing, and the signal cables will run to counting hardware outside the hot cell.

The irradiation module will be designed for experimental flexibility. Around the central sample position, several rings of concentric source holders will permit selection of the ratio of thermal-to-fast neutron flux at the sample by varying source-to-sample distance across the water moderator. For maximum neutron flux, additional sources from the $\mathrm{CUF}{ }^{252} \mathrm{Cf}$ stockpile can be used (up to several hundred milligrams of ${ }^{252} \mathrm{Cf}$ ). The irradiation module will have direct line of sight from the storage pool through an underwater transfer channel into Cell B to permit future installation of a beam line into the cell for applications such as neutron radiography and lowbackground prompt gamma neutron activation analysis (PGNAA). The gamma spectroscopy system will be designed to also accommodate PGNAA studies using in-cell ${ }^{252} \mathrm{Cf}$ sources.

\section{Californium-252 medical sources for tumor therapy}

To convert ${ }^{252} \mathrm{Cf}$ to a physical/chemical form suitable for encapsulation, palladium is deposited onto a fine precipitate of californium oxalate, $\mathrm{Cf}_{2}\left(\mathrm{C}_{2} \mathrm{O}_{4}\right)_{3}$, in an aqueous solution within the hot cell. The Pd-coated particles are dried, calcined to Pd-coated $\mathrm{Cf}_{2} \mathrm{O}_{3}$ cermet material, pressed into a pellet, and then heated to $1600^{\circ} \mathrm{C}$ to melt the $\mathrm{Pd}^{-} \mathrm{Cf}_{2} \mathrm{O}_{3}$ mixture. ${ }^{1}$ After cooling, the melted pellet is rolled into a thin wire on a jeweler's rolling mill. For commercial sales of ${ }^{252} \mathrm{Cf}$, 
$1.1-\mathrm{mm}$ square cermet wires are routinely fabricated with nominal loadings of $200 \mu \mathrm{g}{ }^{252} \mathrm{Cf}$ per $\mathrm{cm}\left(\sim 0.6 \mathrm{wt} \%{ }^{252} \mathrm{Cf}\right)$. For AT sources, wires with lower specific activity must be reduced to diameters $\leq 1 \mathrm{~mm}$ using either a modified rolling mill or a swager with sequentially smaller dies. The remote afterloader sources require cermet wires with a much higher specific activity of ${ }^{252} \mathrm{Cf}$. Terbium was used as a nonradioactive $\mathrm{Cf}$ analog to estimate the maximum practical ${ }^{252} \mathrm{Cf}$ loading in machinable wires. From experience, the higher the weight percent of ${ }^{252} \mathrm{Cf}$, the harder it is to swage tiny wires without splintering or flaking, even with periodic annealing of the wire at high temperatures to improve the workability.

The ${ }^{252} \mathrm{Cf}$ remote afterloader source design will be modeled on the existing geometry for

${ }^{192}$ Ir gamma brachytherapy sources. Fabrication of AT sources will require limited extension of existing fabrication techniques, but the remote afterloader sources will be very challenging because of the design goal of $1 \mathrm{mg}$ of ${ }^{252} \mathrm{Cf}$ combined with very restrictive maximum source dimensions (as small as 5-mm length and 0.34-mm diameter).

\section{Cell-killing studies for boron neutron capture therapy}

T. E. Byrne recently determined the uptake and biological efficacy of four novel boronated compounds for BNCT of the well-characterized human lung cancer cell line A549. ${ }^{5,6}$ The boronated compounds were provided by Professor George Kabalka of The University of Tennessee, Knoxville, Chemistry Department. Two compounds labeled $m$-carboranyl ACBC and LSK 1-38 were boron-containing amino acids, and two compounds labeled CDU-4 and CN-V-264 were boron-containing nucleosides. Chemical diagrams for these compounds are presented in Figure 2. The preirradiation chemical toxicity of each compound was determined by adding known concentrations of each compound to the cell growth medium, incubating the cells 
in petri dishes for 7 days, and then measuring the fraction of cell colonies that exhibited growth. The uptake of boron by the cells was quantified using inductively coupled plasma mass spectroscopy.

To test each compound's effectiveness for BNCT, Dr. Byrne irradiated test tubes containing the boron-impregnated living cells in a partially moderated ${ }^{252} \mathrm{Cf}$ neutron spectrum. The thermal neutron component was approximately $2 \times 10^{8}$ neutrons $\cdot \mathrm{cm}^{-2} \cdot \mathrm{s}^{-1}$ as measured by the activation of manganese wire. Figure 3 shows the experimental arrangement in Cell $\mathrm{C}$ of the CUF including the sample test tube, the source holder, and the cap (in the left manipulator hand). Four sealed sources containing a total of approximately $28 \mathrm{mg}$ of ${ }^{252} \mathrm{Cf}$ were arranged concentrically around the sample test tube, which was inserted through the hole in the cap into the center of the source holder. The hollow source holder was filled with water to provide approximately $3 \mathrm{~cm}$ of moderator from source to sample.

Each sealed test tube enclosed a single smaller sealed vial. Inside this doubly contained system was a $1.0-\mathrm{mL}$ sample of growth medium with between $10^{3}$ and $10^{6}$ A549 cells. A 30sample irradiation matrix included each of the four boronated compounds plus a nonboronated cell standard and a second nonboronated standard of living mink lung cells, with irradiation times of $0.5,1.0,1.5,2.0$, and 4.0 minutes. Following irradiation, the samples were packed in ice and returned to the biology laboratory. Cell $\mathrm{C}$ was ideal for this experiment: the test tubes were dropped through a small-items entry port at the top of the hot cellinto the operating area, and after irradiation the test tubes were retrieved from the hot cell using a sample pull drawer without any opening or manned entry of the cell. 


\section{Results and Discussion}

\section{Californium-252 medical sources for tumor therapy}

Most of the following work used sintered $\left(1300^{\circ} \mathrm{C}\right)$ cermet material of varying $\mathrm{Cf}$-analog content rather than the melted $\left(1600^{\circ} \mathrm{C}\right)$ material that will ultimately be used. A sintered pellet was rolled and swaged until the wire began flaking; then it was sheathed in stainless steel or platinum tubing and swaged as far as possible. The following results must be confirmed by the use of ${ }^{252} \mathrm{Cf}$ rather than terbium and by melted rather than sintered material. The maximum loading of ${ }^{252} \mathrm{Cf}$ to date is $1.8 \mathrm{wt} \%{ }^{252} \mathrm{Cf}\left(12.9 \mathrm{mg}{ }^{252} \mathrm{Cf}\right.$ in $\left.700 \mathrm{mg} \mathrm{Pd}\right)$ in a pellet, but this was not rolled into a wire.

The workability of the sintered material improved significantly after annealing temperatures were raised from 800 to $1050^{\circ} \mathrm{C}$. Two sintered pellets with nominal loading of $5.8 \mathrm{wt} \%{ }^{252} \mathrm{Cf}$-equivalent were rolled and swaged to 0.66 - and $0.46-\mathrm{mm}$ diameters and then sheathed in stainless steel tubing and swaged to $0.27-\mathrm{mm}$ diameter, well within the design goal of $0.34 \mathrm{~mm}$. Other tests with Pt-10\% Ir alloy sheath material indicated easier workability than with stainless steel. For recycling purposes a Pd sheath will be used, with workability expected to be comparable to that of Pt. These results are an improvement over early studies which used $\mathrm{Sm}_{2} \mathrm{O}_{3}$ in place of $\mathrm{Cf}_{2} \mathrm{O}_{3}$ in a Pd matrix and reported that dense cermet pellets with $2 \mathrm{wt} \%$ ${ }^{252} \mathrm{Cf}$-equivalent could be rolled down to $0.76 \mathrm{~mm}$ while $4 \mathrm{wt} \%{ }^{252} \mathrm{Cf}$-equivalent would lead to splintering of the wire. ${ }^{7}$ The physical properties of $\mathrm{Sm}_{2} \mathrm{O}_{3}$ and $\mathrm{Tb}_{2} \mathrm{O}_{3}$ in the cermet wire should be comparable for the same loadings.

Ongoing research in rare earth-transition metal alloys has been promising. The synthesis of a Cf-analog alloy has been demonstrated with good machinability. If practicality of use with 
${ }^{252} \mathrm{Cf}$ is confirmed in follow-up testing, the maximum source strengths available could be significantly increased over those using $\mathrm{Pd}-\mathrm{Cf}_{2} \mathrm{O}_{3}$ cermet wire. The remote afterloader source must be licensed as a Special Form source for transportation. Additionally, the issue of internal pressure buildup within the source from alpha decay of ${ }^{252} \mathrm{Cf}$ will require close scrutiny.

\section{Cell-killing studies for boron neutron capture therapy}

All four boronated compounds exhibited toxicity to the A549 cell cultures at growth medium concentrations as low as $1.25 \mu \mathrm{g} \mathrm{B} / \mathrm{mL}$. The amino acids LSK and ACBC suppressed all cell growth at concentrations $>10 \mu \mathrm{g} \mathrm{B} / \mathrm{mL}$; the nucleosides CDU-4 and $\mathrm{CN}-\mathrm{V}-264$ suppressed all growth above $2.5 \mu \mathrm{g} \mathrm{B} / \mathrm{mL}$. These concentrations $10 \mu \mathrm{g} \mathrm{B} / \mathrm{mL}$ and $2.5 \mu \mathrm{g} \mathrm{B} / \mathrm{mL}$, respectively, were used in the incubation of cells prior to irradiation. At those concentrations the measured cell survival after 7 days was as follows: ACBC, $8 \%$; LSK, $2 \%$; CDU-4, 6\%; and CN-V-264, 4\%. Prior to irradiation the cell cultures were grown for 24 hours in the boronated growth medium with these measured cell survivals: ACBC, $52.1 \%$; LSK, 22.4\%; CN-V-264, 18.1\%; and CDU-4, $17.5 \%$.

Analytical measurements of boron uptake by the cells provided the following (in units of $10^{9}$ atoms of ${ }^{10} \mathrm{~B}$ per cell): $\mathrm{ACBC}, 2749$; LSK, 96; CN-V-264, 50; and CDU-4, 10. A minimum of $10^{9}$ atoms of ${ }^{10} \mathrm{~B}$ per cell is typically required for BNCT. This minimum was exceeded by the four compounds but sometimes at a cost of significant cellular toxicity. Use of isotopically enriched ${ }^{10} \mathrm{~B}$ compounds would provide a fivefold increase in ${ }^{10} \mathrm{~B}$ cellular content for the same toxicity and thus mitigate toxicity concerns. The efficacy of cell killing by ${ }^{252} \mathrm{Cf}$ irradiation was represented by an effective kill constant calculated for each compound. Nonboronated control samples gave a kill constant of 1.39 (reflecting some cell killing by fast neutron damage 
mechanisms). The kill constants for the compounds demonstrated their effectiveness for enhanced cell killing: ACBC, 2.71; LSK 2.64; CDU-4, 2.88; and CN-V-264, 2.87.

\section{Summary}

If the ${ }^{252} \mathrm{Cf}$-based NAA facility becomes available as is currently planned, the FDA would have available an automated analysis system for food samples without scheduling concerns for reactor downtime. The CUF would have a very useful irradiation and gamma spectroscopy facility with more flexibility for irradiation schedules and sample and irradiation configuration than is typically available with reactor-based systems.

For the ${ }^{252} \mathrm{Cf}$ medical sources, development work indicates that ${ }^{252} \mathrm{Cf}$ loading can be increased an order of magnitude over current wire fabrication. Remotely operated swaging equipment currently under development will permit fabrication of AT sources at ORNL in 1997, confirmation of the $\mathrm{Cf}$-analog loadings in cell using ${ }^{252} \mathrm{Cf}$, and ultimately the fabrication and licensing of small high-activity remote afterloader sources. Remote afterloader sources containing several hundred micrograms of ${ }^{252} \mathrm{Cf}$ are expected based on current methods, and advances in the material science could increase that to $>1 \mathrm{mg}$ of ${ }^{252} \mathrm{Cf}$. After successful resolution of design and licensing issues, high-activity remote afterloader sources could be available by 2000 .

All four BNCT compounds enhanced cell killing in a neutron field. ACBC was very promising for future research, with low toxicity and excellent cellular uptake. LSK 1-38 and CN-V-264 exhibited lower cellular uptake, and the results suggest secondary study after ACBC. CDU-4 exhibited the highest cellular toxicity and lowest uptake of the four; therefore, further 
research is not suggested. The CUF was demonstrated to be ideally configured for future irradiation experiments such as these BNCT studies.

A potential user can access the CUF by calling (423) 576-2280 and then submitting a proposal to

\author{
Californium User Facility \\ Oak Ridge National Laboratory \\ P.O. Box 2008, MS-6385 \\ Oak Ridge, TN 37831
}

Acceptance of proposals depends on scientific merit, suitability of the CUF for the proposed project, and appropriateness of the work to U.S. Department of Energy and CUF objectives. After acceptance of the proposal, the specific operating procedures, time allotted for work, user fees (if any), and collaborative arrangements will be determined. A centralized Office of Science and Technology Partnerships executes a user agreement between the user institution and Lockheed Martin Energy Research Corporation, the managing contractor of ORNL. This agreement stipulates the terms and conditions for the interaction.

The CUF is unclassified and is located in an uncleared access area adjacent to the HFIR complex. Visitors and users must be issued passes by ORNL. CUF staff oversee all experimental arrangements to ensure that activities are conducted within the requirements of the facility safety documentation. After the users receive REDC-specific access training, CUF staff will facilitate user access into the hot cell facilities for experiment setup, transfer and position ${ }^{252} \mathrm{Cf}$ sources as needed, and coordinate work with other REDC service groups. Access to the hot cell areas is 
governed by existing operating procedures under the guidance of on-site Health Physics personnel and must be coordinated with ongoing operations. The Californium-252 Newsletter is periodically issued to provide information of current interest to ${ }^{252} \mathrm{Cf}$ users and is available upon request from the address given above.

\section{Acknowledgements}

The authors would like to thank Dr. James Tanner of the FDA for his collaboration and planning of the NAA system; David Glasgow of the ORNL Chemical and Analytical Sciences Division for planning of NAA and gamma spectroscopy; Dr. Jacek Wierzbicki, Dr. James Fontanesi, and Mark Rivard of Harper Hospital, Wayne State University, for collaboration in the development of ${ }^{252} \mathrm{Cf}$ medical sources; Professor George Kabalka of The University of Tennessee, Knoxville, Chemistry Department, for supplying the boronated compounds for BNCT studies; Margaret Terzaghi-Howe of the ORNL Analytical Chemistry Division for providing the cell line for BNCT studies; and Douglas Duckworth of the ORNL Chemical and Analytical Sciences Division for providing boron chemical analyses.

\section{References}

1. J. B. KNAUER, R. C. MARTIN, Californium-Isotope for 21 st Century Radiotherapy, J. G. WIERZBICKI (Ed.), Kluwer Academic Publishers, Dordrecht, Netherlands, 1997 (in press). 
2. I. W. OSBORNE-LEE, C. W. ALEXANDER, Californium-252: A Remarkable Versatile Radioisotope, ORNL/TM-12706, Oak Ridge National Laboratory, Oak Ridge, Tenn., 1995.

3. Y. MARUYAMA, J. R. VAN NAGELL, J. YONEDA, E. S. DONALDSON, H. H. GALLION, D. POWELL, R. J. KRYSCIO, Cancer, 68 (1991) 1189.

4. S. REUCROFT, R. RUSACK, D. RUUSKA, J. SWAIN, Neutron Irradiation of APDs Using ${ }^{252} \mathrm{Cf}$, NUB-3132, Northeastern University, Boston, Mass., 1996.

5. T. E. BYRNE, In Vitro Determination of Uptake and Biological Efficacy of Boronated Compounds for Neutron Capture Therapy in the Human Lung Cancer Cell Line A549, The University of Tennessee, Knoxville, dissertation, 1996.

6. T. E. BYRNE, L. F. MILLER, R. MARTIN, D. DUCKWORTH, M. TERZAGHI-HOWE, G. W. KABALKA, Determination of Uptake and Efficacy of Compounds for Boron Neutron Capture Therapy, to be presented at the Health Physics Society Annual Meeting, San Antonio, Texas, June 29-July 3, 1997.

7. W. C. MOSLEY, P. K. SMITH, P. E. McBEATH, Palladium $-{ }^{252}$ Cf Oxide Cermet, An Improved Form for ${ }^{252} \mathrm{Cf}$ Sources, DP-MS-72-4, Savannah River Laboratory, Aiken, S.C., 1972. 


\section{Figure Captions}

Figure 1. Floor plan of the Californium Facility. The Californium User Facility includes

Cell B, Cell C, the storage pool, the pneumatic transfer lines, and the sealed ${ }^{252} \mathrm{Cf}$ sources.

Figure 2. Boronated compounds used in the BNCT cell-killing studies (from Ref. 5).

Figure 3. Experimental configuration for testing effectiveness of boronated compounds in killing cancer cells in a ${ }^{252} \mathrm{Cf}$ neutron field for BNCT studies. 


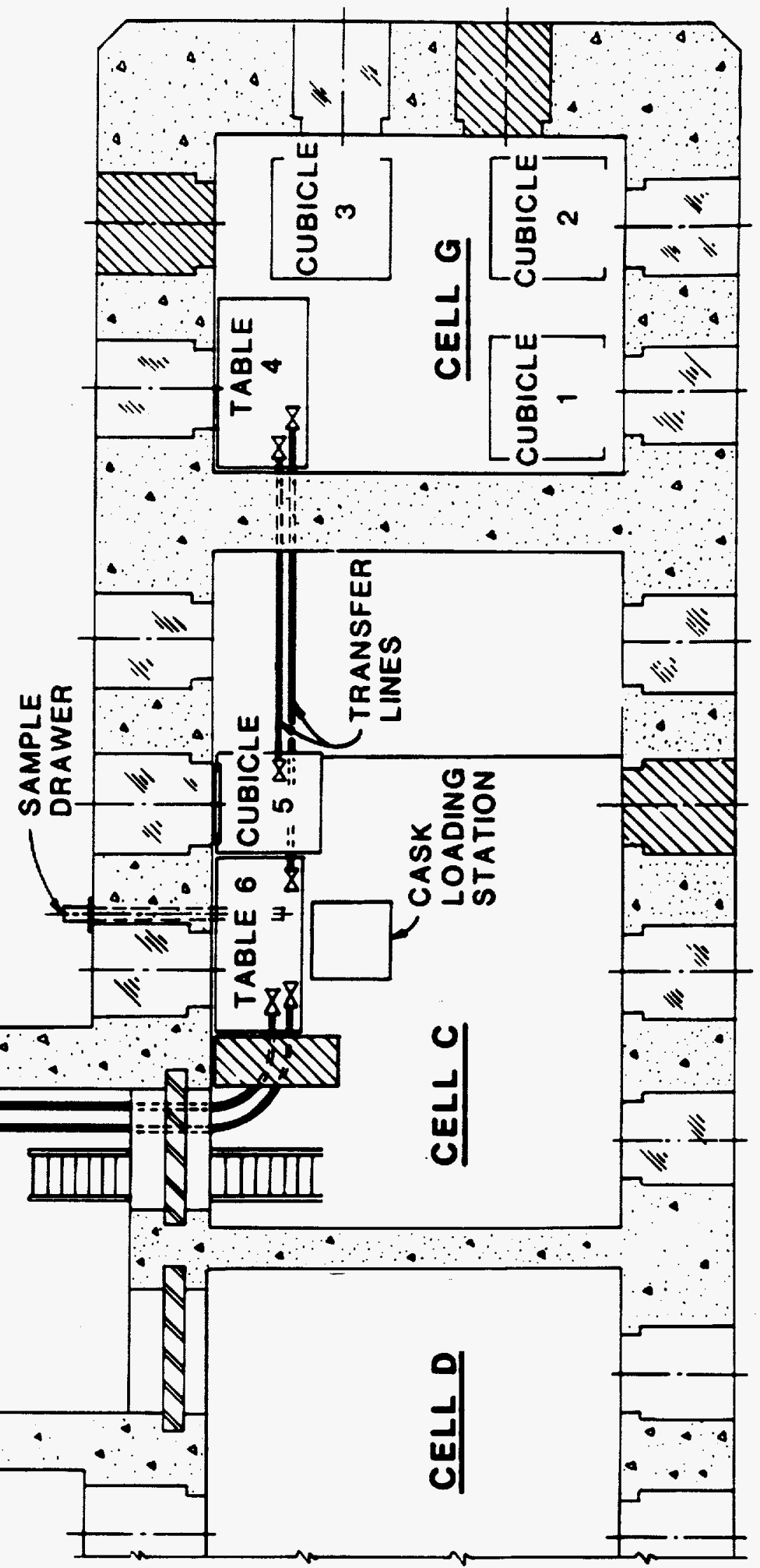


CDU -4

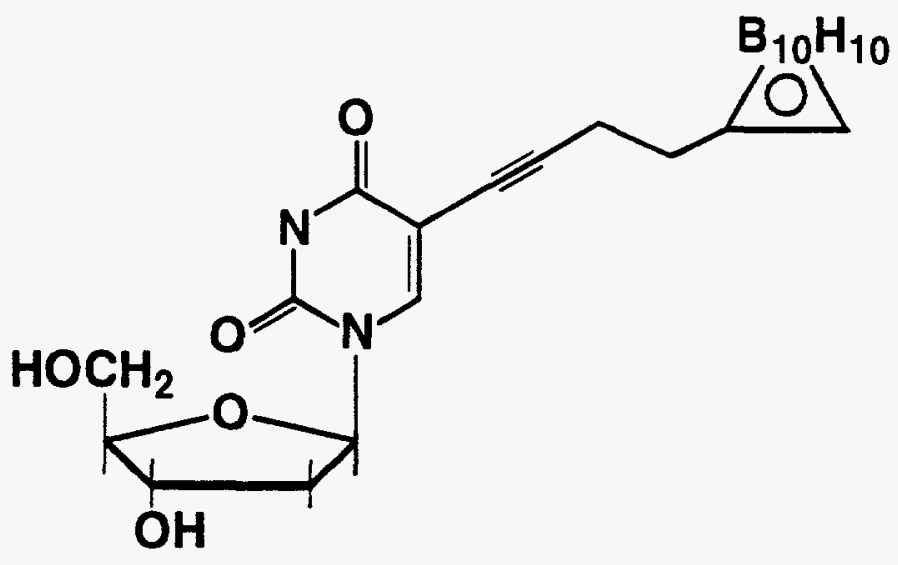

CN - V-264

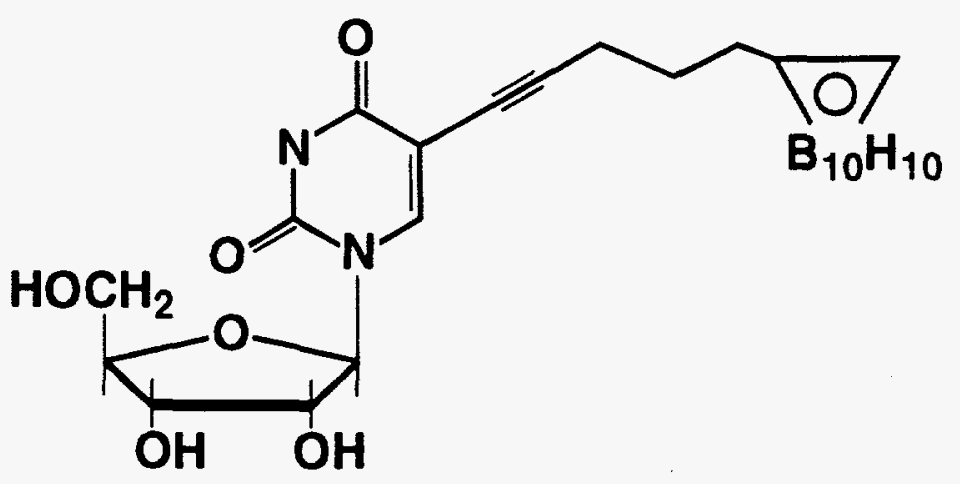

LSK 1-38

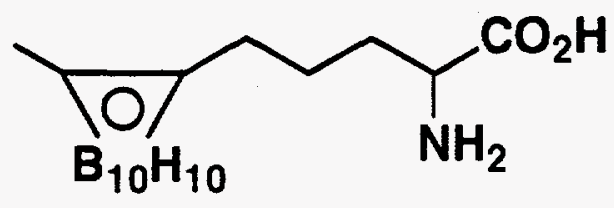

$m$ - CARBORANYL ACBC

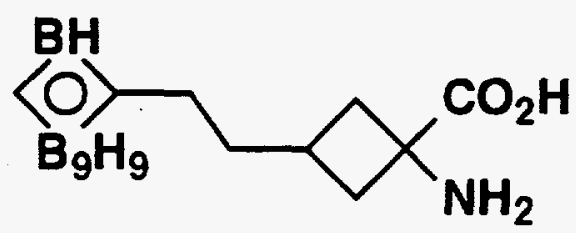

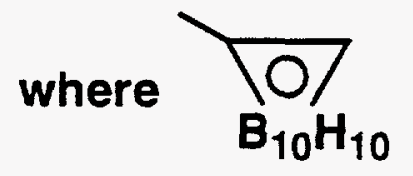

where represents o-carborane $\left(\mathrm{C}_{2} \mathrm{~B}_{10} \mathrm{H}_{12}\right)$

represents $m$ - carborane $\left(\mathrm{C}_{2} \mathrm{~B}_{10} \mathrm{H}_{12}\right)$ 


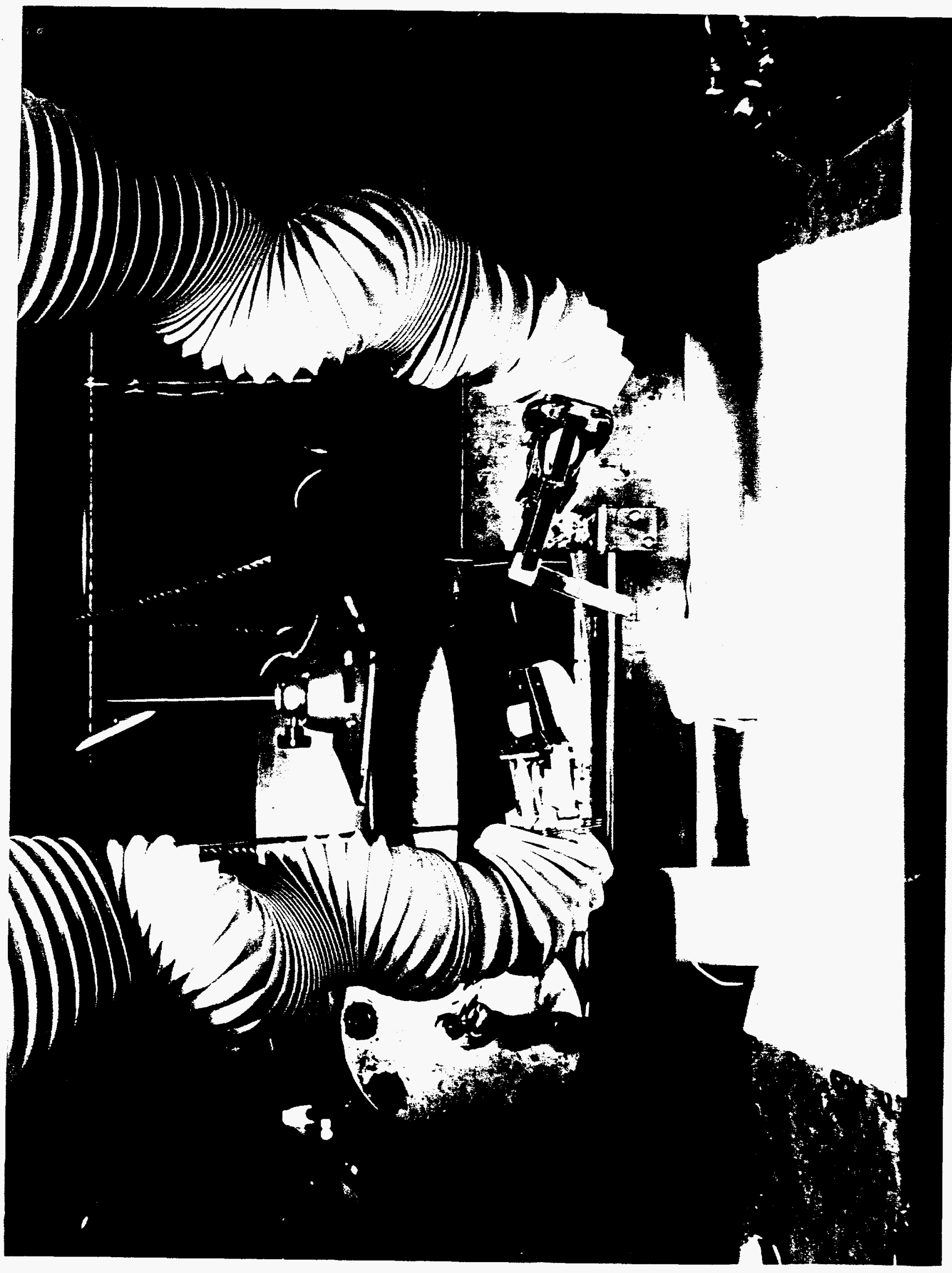

